\title{
Phytoremediation Potential of Indigenous Plants Growing at Nchanga Mine in Chingola, Zambia
}

\author{
Lupupa Kachenga* ${ }^{\circledR}$, Harry Nixon Chabwela, Kasuka Mwauluka \\ Department of Biological Sciences, University of Zambia, Lusaka, Zambia \\ Email: *tembolk@gmail.com
}

How to cite this paper: Kachenga, L., Chabwela, H.N. and Mwauluka, K. (2020) Phytoremediation Potential of Indigenous Plants Growing at Nchanga Mine in Chingola, Zambia. Open Journal of Ecology, 10, 45-61.

https://doi.org/10.4236/oje.2020.102004

Received: October 30, 2019

Accepted: February 17, 2020

Published: February 20, 2020

Copyright $\odot 2020$ by author(s) and Scientific Research Publishing Inc. This work is licensed under the Creative Commons Attribution International License (CC BY 4.0).

http://creativecommons.org/licenses/by/4.0/

\begin{abstract}
Mining and smelting processes are among the key sources of soil contamination by heavy metals resulting in dramatic disturbances and loss of biodiversity. Native plants growing naturally in hostile mining environments can be used for management, decontamination and possible rehabilitation of polluted soils. These plants are either excluders or accumulators based on their Bioaccumulation Factors (BAF). This, therefore requires identification of native plants that are able to accumulate heavy metals in their plant tissues at concentrations higher than that in the soil in which they are growing. This study investigated the phytoremediation potential of indigenous plants growing at the tailings dams of Nchanga Mine in Chingola, Zambia. TD4 and a site $50 \mathrm{~m}$ away from TD4 were sampled as Sampling Areas One (1) and Two (2), respectively. TD4 was divided into four quadrants and three plots from each quadrant were randomly sampled. Three plots from each of the two quadrants from Sampling Area Two were also sampled. Composite soil samples were collected from the plots and a total of 175 individuals of 16 grass and herbaceous plant species were collected and analysed. Atomic Absorption Spectrophotometry was used to determine the concentrations of Copper $(\mathrm{Cu})$ and $\mathrm{Zinc}(\mathrm{Zn})$ in the soils and plant specimens. The findings of the study showed that the concentrations of $\mathrm{Cu}$ and $\mathrm{Zn}$ in the soil ranged from $891.41 \mathrm{mg} / \mathrm{kg}$ to $15,617.47 \mathrm{mg} / \mathrm{kg}$ and $20.73 \mathrm{mg} / \mathrm{kg}$ to $96.85 \mathrm{mg} / \mathrm{kg}$, respectively. Arthraxonquartinianus had the highest concentration of $\mathrm{Cu}$ (1016.8 mg/kg) while Cyperusrotundus had the lowest $(29.35 \mathrm{mg} / \mathrm{kg})$. Arthraxonquartinianus had the highest concentration of $\mathrm{Zn}(192.8 \mathrm{mg} / \mathrm{kg})$ and Crinum had the lowest $(28.24 \mathrm{mg} / \mathrm{kg})$. BAF values for $\mathrm{Cu}$ were less than 1 in all the plants and BAF values for $\mathrm{Zn}$ were highest in Arthraxonquartinianus (10.77) with Crinum having the lowest BAF of 0.01. The Bioaccumulation Factors indicated that all the plant species studied are $\mathrm{Cu}$ excluders; and with
\end{abstract}


the exception of Crinum, all were $\mathrm{Zn}$ accumulators and Arthraxonquartinianus, a hyperaccumulator of $\mathrm{Zn}$.

\section{Keywords}

Accumulators, Excluders, Indigenous Plants, Phytoremediation

\section{Introduction}

The mining industry is the backbone of Zambia's economy making up $80 \%$ of foreign earnings [1]. A large proportion of the world's minerals come from developing countries such as Brazil, China, including Zambia. However, mining is one of the anthropogenic activities causing some of the most dramatic disturbances on biodiversity, water quality, and land use [2]. Increased mining activity increases the amount of degraded land. The degraded land includes bare stripped areas, loose soil piles, waste rock and overburden surfaces and subsided land areas. Surface mining or open pit mining causes up to 11 times more land destruction compared to underground mining; fertile land is transferred into wasteland or bog and local status of water and landscape deteriorates with some ecosystems being entirely destroyed [3] [4].

Mining and smelting processes are among the key sources of heavy metal contamination of soil and water [5]. Although many metals are essential, all metals are toxic at a high concentration due to the oxidative stress that they cause by formation of free radicals, as well as disrupting the function of pigments and enzymes [6]. As a result, soil contaminated with heavy metals is rendered unsuitable for plant growth, thereby resulting in the loss of biodiversity [7].

In the recent past, there has been increasing concern for the environment and as such, post-mining reclamation of degraded land should be an integral feature of the mining spectrum [2]. Reclamation is the process by which highly degraded land is returned to productivity and some measure of biotic function and productivity is restored [8]. There are a number of methods that have been used to cope with the soil pollution of degraded lands. Current techniques include excavation, chemical stabilization, soil washing or soil flushing [9], but these methods are sophisticated techniques and are suitable for relatively small soil volumes at sites that require immediate action [6] [9]. They are costly, time consuming and sometimes environmentally destructive rendering the soil unusable after treatment [10] [11].

In recent years, there are cost effective technologies that have been generated by scientists and engineers. These include the use of microorganisms/biomass or live plants to clean up the polluted areas and phytoremediation.

Phytoremediation is an emerging cost effective technology that has aesthetic advantages and long term applicability [12] [13]. Phytoremediation is an integrated multidisciplinary approach and involves the efficient use of plants to 
eliminate, detoxify or immobilize environmental contaminants that are present in a growth matrix such as soil, water or sediments, through the natural, biological, chemical or physical processes of the plants [12]. The vegetation is capable of improving the nutrient conditions of the soil thereby setting the base for establishment of self-sustaining vegetation cover [14].

Metal tolerant plants are able to grow in contaminated soils as they have evolved mechanisms to minimize the effects of exposure to heavy metals [15]. Plants that are able to take up heavy metals to a greater concentration than that in the soil in which it is growing are called Hyperaccumulator plants [16] [17]. Hyperaccumulators that grow in polluted areas can accumulate large concentrations of heavy metals in their shoots; consequently, the removal of metals from the soil can be enhanced considerably by the judicious selection of plant species [18]. Some plants are excluders, meaning, they restrict the transport of heavy metals to the shoot and maintain relatively low concentrations of heavy metals [15]. Therefore, it is important to search for plants that spontaneously colonize these disturbed sites [9]. Research has shown that native plants growing naturally in hostile mining environments are potential phytoremediators and can be used to rehabilitate the disturbed sites [19]. Identification of indigenous hyperaccumulator plants is therefore imperative for the successful implementation of phytoremediation for mine reclamation mainly because native plant species require less management and they are acclimatized to the native climatic conditions and seasonal cycle [20] [21] [22].

Most $\mathrm{Cu}$ and $\mathrm{Zn}$ hyperaccumulator plants that have been identified are specific to Europe, Asia, the USA, and other African Countries like Congo DR and Zimbabwe. However, few species of Zambian native vegetation have been identified, namely, Cheilanthesperlanata, Eragrostisracemosa, Bulbostylispseudoperennis, Aspilia ciliate, Conyzacordat, Persicariapuncataand Persicariacapitata [23] [24].

The general objective of this study was to assess the phytoremediation potential of indigenous plants growing at the Nchanga Mine Tailings in Chingola, Zambia.

The hypotheses being tested in the study were: that the plants growing at the study site at Nchanga Mine had no potential for phytoremediation of $\mathrm{Cu}$ and $\mathrm{Zn}$ and that there was no relationship between the concentrations of $\mathrm{Cu}$ and $\mathrm{Zn}$ in the soil and in the plant species growing at the study site.

\section{Materials and Methods}

\subsection{Study Area}

The study was conducted at Nchanga Mine in Chingola. Chingola is a town in the Copperbelt Province of Zambia. It is situated at an elevation of 1340 meters above sea level on the Central African Plateau, $12^{\circ} 30^{\prime} \mathrm{S}$ latitude, $27^{\circ} 50^{\prime} \mathrm{E}$ Longitude [25]. Nchanga Mine which has the largest Open Pit Mine in Africa is operated by Konkola Copper Mines (KCM) Plc. The mine workings lie in an arc 
which is $11 \mathrm{~km}$ long around the west and north of the town (Figure 1), covering nearly $30 \mathrm{~km}^{2}$ [26], as such, the extent of the land degradation and soil contamination by heavy metals is of serious concern.

\subsection{Sampling and Analysis}

\subsubsection{Plant and Soil Sampling}

A stratified random sampling approach was used. Two sampling areas were established; one at the Tailings Dam four (TD4) (Figure 1) as sampling Area one (01) and the other covering the immediate vicinity of the tailings impoundment which served as the control site. Each sampling area was divided into four quadrats using a compass. In each quadrat, nine (9) $10 \mathrm{~m} \times 10 \mathrm{~m}$ plots were established and three were randomly picked and sampled.

For each plant species present in each plot, at least three individuals were collected. The plant specimens were tagged, put in a polythene bag and placed in a cooler box. The plant specimens were identified using taxonomic keys and unidentified specimens were pressed and identified using voucher specimen in the University of Zambia Herbarium.

A soil probe was used to collect soil samples at depths of $15-20 \mathrm{~cm}$. Three soil samples were collected in each plot at different points. A composite sample from each plot was then obtained by mixing the three samples well. The composite samples were placed in labelled polythene bags and stored in airtight containers.

\subsubsection{Plant Diversity Study}

A line transect was laid in each quadrat, running north to south. A square $1 \mathrm{~m} \times$ $1 \mathrm{~m}$ grid was used to record the plant species present and the number of individuals. The grid was placed along the transect every two meters and the species present in the grid were recorded.

\subsubsection{Quantitative Analysis}

The important quantitative analysis such as density, frequency, and abundance

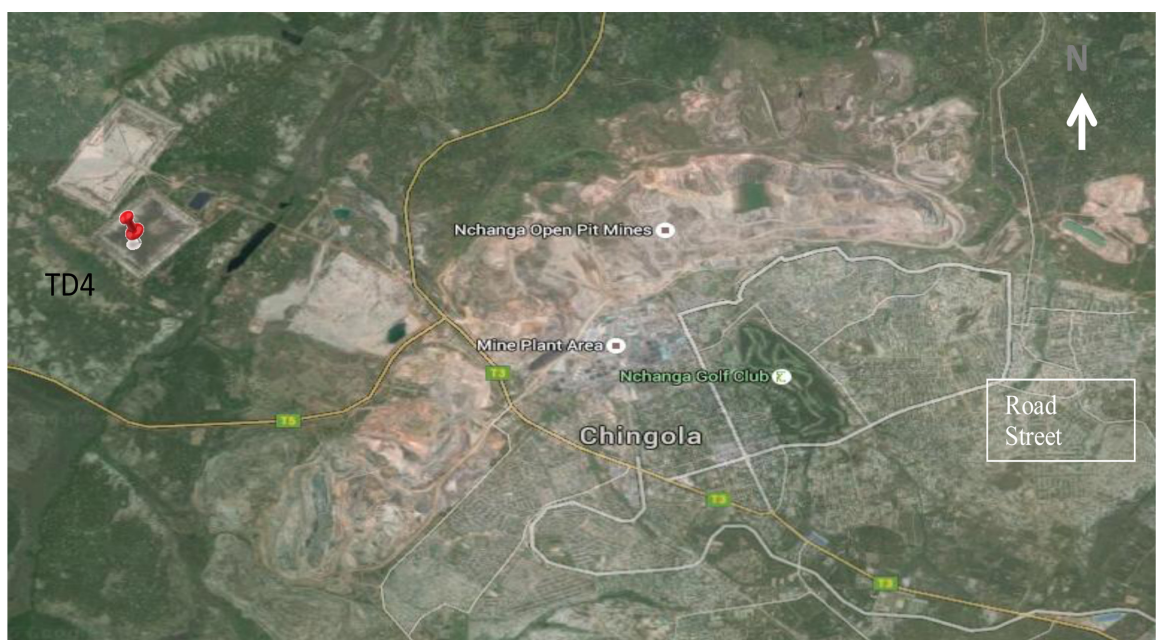

Figure 1. Map showing location of Nchanga open pit mine workings and TD4 (Google earth). 
of the herbs and grass species were determined according to Curtis and McIntosh [27]. The Species richness was calculated using the method "Margalef's index of richness" $\mathrm{D}_{\mathrm{mg}}$ [28]. The species diversity was computed using the Shannon-Wiener Index (H') [28].

\subsubsection{Chemical Analysis of the Soil Samples}

The soil samples were air dried in the laboratory at room temperature by spreading them out on transparent plastic for seven days. The samples were then passed through a $2 \mathrm{~mm}$ sieve and ashed in porclain crucibles in a furnace at $450^{\circ} \mathrm{C}$ for three hours. Acids used in the extraction of the heavy metals were all Analytical Grade. One gram of each of the soil samples was placed in a $200 \mathrm{~mL}$ conical flask, to which $0.2 \mathrm{~mL}$ of sulfuric acid. $1 \mathrm{~mL}$ Nitric acid and $5 \mathrm{~mL}$ of perchloric acid were added too. The mixture was then placed on a hotplate and heated to $180^{\circ} \mathrm{C}$ for 15 minutes. The mixture was allowed to cool and then filtered through Whatman No. 42 filter paper into $100 \mathrm{~mL}$ volumetric flasks. Distilled water was added to the mark. The filtrate was then transferred to $100 \mathrm{~mL}$ plastic bottles.

The concentrations of the $\mathrm{Cu}$ and $\mathrm{Zn}$ were determined using an Atomic $\mathrm{Ab}$ sorption Spectrophotometer (AAS), Analyst ${ }^{\mathrm{TM}} 900$ (Perkin Elmer Instrument, USA) with an acetylene flame. The concentration of the heavy metals were calculated in $\mathrm{mg} / \mathrm{kg}$ dry weight.

\subsubsection{Chemical Analysis of the Plant Samples}

Plant samples were dusted with a light brush and then dried at room temperature in the laboratory for one week. They were then placed in an electric steel oven for at least three hours at $110^{\circ} \mathrm{C}$ before being ground using a steel grinding mill. $3 \mathrm{~g}$ of each of the ground and dried samples were then ashed in a controllable muffle furnace at $450^{\circ} \mathrm{C}$. the resulting ash was dissolved in $20 \mathrm{ml}$ of $1 \mathrm{M}$ analytical grade nitric acid and the solution was evaporated to near dryness. The samples were then filtered through ashless Whatman filter paper into $100 \mathrm{~cm}^{3}$ volumetric flasks. The residue on the filter paper was washed several times with distilled deionised water. The resulting filtrate was diluted to the mark using distilled deionised water. The concentrations of $\mathrm{Cu}$ and $\mathrm{Zn}$ were then determined using an Atomic Absorption Spectrophotometer, as in the soil samples above.

\subsubsection{Analysis of Phytoremediation Potential}

The phytoremediation potential was assessed by calculating the bioaccumulation factor (BAF).

$$
\text { BAF shoot }=\left({ }_{c} \text { shoot }\right) /\left({ }_{c} \text { soil }\right)
$$

where ${ }_{C}$ shoot is the metal concentration in the shoots and ${ }_{c}$ soil is the metal concentration in the soil [29].

Plants that have a BAF shoot value greater than one are accumulators, whereas, plants that have BAF shoot values less than one are considered excluders [15] [29]. 


\section{Results and Discussion}

\subsection{Concentrations of $\mathrm{Cu}(\mathrm{mg} / \mathrm{kg})$ and $\mathrm{Zn}(\mathrm{mg} / \mathrm{kg})$ in the Soil}

The study site was characterized by high concentrations of $\mathrm{Cu}$ and $\mathrm{Zn}$ as was expected, considering the fact that the study site was located in the mine area, and at an old tailings dump to be precise. The $\mathrm{Cu}$ and $\mathrm{Zn}$ concentrations in the soil ranged from $2342.04 \mathrm{mg} / \mathrm{kg}$ to $12,024.49 \mathrm{mg} / \mathrm{kg}$ and $24.22 \mathrm{mg} / \mathrm{kg}$ to 67.99 $\mathrm{mg} / \mathrm{kg}$ respectively (Table 1 ). The quadrats in TD4 had some of the highest values, compared to quadrats in the control site, $50 \mathrm{~m}$ away from TD4. The results showed that the soil had very high concentrations of $\mathrm{Cu}$, much higher than the threshold value of $20 \mathrm{mg} / \mathrm{kg}$ according to WHO [30] and $130 \mathrm{mg} / \mathrm{kg}$, according to ICRCL [31]. The concentrations of $\mathrm{Zn}$ were higher than the permissible values of $40 \mathrm{mg} / \mathrm{kg}$ according to WHO [30], but below the threshold value of 300 $\mathrm{mg} / \mathrm{kg}$ according to ICRCL [31].

Soils from S1 had the highest concentration of $\mathrm{Cu}(12,024.49 \mathrm{mg} / \mathrm{kg})$, followed by W1 $(5700.45 \mathrm{mg} / \mathrm{kg})$ and N1 $(5364.67 \mathrm{mg} / \mathrm{kg})$. With regards to Zn, S1 had the highest concentration $(67.99 \mathrm{mg} / \mathrm{kg})$ followed by $\mathrm{N} 1(34.05 \mathrm{mg} / \mathrm{kg})$ and E1 $(32.44 \mathrm{mg} / \mathrm{kg})$. The difference in the concentrations of $\mathrm{Cu}$ and $\mathrm{Zn}$ in the quadrats in TD4 can be attributed to the direction of flow of the tailings discharged into the tailings dump. The flow is from north to south, with the most tailings settling on the southern part of the tailings dump. The dump is in such a way that it slants to the south. The high concentrations in the immediate vicinity of the tailings dump, $50 \mathrm{~m}$ away had $\mathrm{Zn}$ and $\mathrm{Cu}$ concentrations which were ranging from $2343.04 \mathrm{mg} / \mathrm{kg}$ to $4381.25 \mathrm{mg} / \mathrm{kg}$, which however, lower than TD4, are still higher than recommended values. This may be due to waste rock, leachate from mine tailings and deposition of wind-blown particulates from piles [32].

\subsection{Concentrations of $\mathrm{Cu}$ and $\mathrm{Zn}$ in the Plants Growing at TD4}

A total of 175 individuals of 16 plant species were collected and analyzed for heavy metals. According to WHO [30], the maximum acceptable values of $\mathrm{Cu}$ and $\mathrm{Zn}$ in plants is $10 \mathrm{mg} / \mathrm{kg}$ and $50 \mathrm{mg} / \mathrm{kg}$, respectively. The $\mathrm{Zn}$ content of plants in this study was ranging from $26.47 \mathrm{mg} / \mathrm{kg}$ to $174.32 \mathrm{mg} / \mathrm{kg}$, with

Table 1. Mean concentrations of $\mathrm{Cu}$ and $\mathrm{Zn}$ in the soil cover and Tailings at TD4 and the site $50 \mathrm{~m}$ away from TD4.

\begin{tabular}{cccccccccc}
\hline \multirow{2}{*}{ Sampling Area } & \multicolumn{4}{c}{} & \multicolumn{3}{c}{ Cu mg/kg } & \multicolumn{4}{c}{ Zn mg/kg } \\
\cline { 2 - 10 } & & Mean & SE of Mean & Median & Range & Mean & SE of Mean & Median & Range \\
\hline \multirow{2}{*}{ TD4 } & N1 & 5364.67 & 349.36 & 6042.54 & $1042.06-6720.92$ & 34.05 & 0.65 & 32.35 & $27.58-37.94$ \\
& E1 & 4943.95 & 153.79 & 4737.41 & $3857.34-6023.37$ & 32.44 & 0.58 & 31.66 & $27.59-36.34$ \\
& S1 & 12024.49 & 455.95 & 12397.77 & $8925.36-15,617.47$ & 67.99 & 4.11 & 59.74 & $42.91-96.85$ \\
\multirow{2}{*}{$\begin{array}{c}\text { Site 50 m away } \\
\text { from TD4 }\end{array}$} & W1 & 5700.45 & 99.53 & 5857.67 & $5196.85-6214.71$ & 30.41 & 0.73 & 30.90 & $25.84-33.46$ \\
& N2 & 2342.04 & 401.24 & 1813.80 & $891.41-5112.44$ & 24.22 & 0.86 & 23.59 & $20.73-29.99$ \\
& W2 & 4381.25 & 350.12 & 3900.72 & $2403.52-6251.75$ & 28.85 & 0.34 & 29.69 & $26.99-30.84$ \\
\hline
\end{tabular}


Digitariaeriantha, cornyzacordata and Arthraxonquartinianus having higher values. Plant species with some of the high values of $\mathrm{Cu}$ concentration recorded included Arthraxonquartinianus (1016.8 mg/kg), Digitariaeriantha (1282.2 $\mathrm{mg} / \mathrm{kg}$ ) and Vernonia (588 mg/kg) (Table 2). Cu content in plants was lowest in Cyperusrotundus $(20.99 \mathrm{mg} / \mathrm{kg})$ and Crinum $(50.2 \mathrm{mg} / \mathrm{kg})$. The concentration of Zinc in the plants (Table 3 ) was mostly above the recommended values according to WHO [30], but below the threshold value of $300 \mathrm{mg} / \mathrm{kg}$ according to ICRCL [31].

\subsection{Correlation between Soil Metal Concentration and Plant Metal Concentration}

Table 4 and Table 5 show the correlation coefficient between soil $\mathrm{Cu}$ and $\mathrm{Zn}$ concentration and the concentration of $\mathrm{Zn}$ and $\mathrm{Cu}$ in the plant species. The correlation between $\mathrm{Cu}$ concentration in the soil and $\mathrm{Cu}$ concentration in the plant species is 0.376 , whereas, the correlation between concentration of $\mathrm{Zn}$ in the soil and concentration of $\mathrm{Zn}$ in the plant species is 0.359 . The correlation coefficient is weak, but positive. This shows that there is a positive relationship between the concentration of $\mathrm{Cu}$ and $\mathrm{Zn}$ in the soil and $\mathrm{Cu}$ and $\mathrm{Zn}$ concentrations in the plants.

This weak positive correlation indicates that the concentration of the heavy metals in the plants is weakly correlated to the concentration of the heavy metals in the soil. It is thus expected that when the concentration of the heavy metals in

Table 2. Mean concentrations of $\mathrm{Cu}(\mathrm{mg} / \mathrm{kg})$ in the plant species in the sampling sites.

\begin{tabular}{|c|c|c|c|c|c|c|c|c|c|c|c|c|}
\hline \multirow[b]{2}{*}{ Species } & \multicolumn{2}{|c|}{ N1 } & \multicolumn{2}{|c|}{$\mathrm{N} 2$} & \multicolumn{2}{|c|}{ E1 } & \multicolumn{2}{|c|}{ S1 } & \multicolumn{2}{|c|}{ W1 } & \multicolumn{2}{|c|}{ W2 } \\
\hline & Mean & $\begin{array}{l}\text { SE of } \\
\text { Mean }\end{array}$ & Mean & $\begin{array}{l}\text { SE of } \\
\text { Mean }\end{array}$ & Mean & $\begin{array}{l}\text { SE of } \\
\text { Mean }\end{array}$ & Mean & $\begin{array}{l}\text { SE of } \\
\text { Mean }\end{array}$ & Mean & $\begin{array}{l}\text { SE of } \\
\text { Mean }\end{array}$ & Mean & $\begin{array}{l}\text { SE of } \\
\text { Mean }\end{array}$ \\
\hline Crinum L. & 58.91 & 0.69 & & & & & & & & & 50.2 & \\
\hline Anthephora Schreb. & 132.92 & 9.31 & 43.17 & 10.31 & 65.78 & 5.92 & 139.63 & 4.03 & 360.7 & 11.62 & 29.35 & 0.49 \\
\hline Digitariaeriantha Stued. & 135.61 & 8.13 & 144.94 & 3.04 & 64.77 & 2.33 & 1282.2 & 68.71 & 578.9 & 21.71 & 91.4 & 3.05 \\
\hline Sp 21 & 450.85 & & & & & & & & 449 & 1.77 & & \\
\hline Sp 27 & 118.86 & 5.22 & 112.47 & & & & & & & & 213.56 & 34.25 \\
\hline Nephrolepis Schott & 207.83 & 9.37 & & & 221.15 & 22.24 & & & & & 228.15 & 2.59 \\
\hline Senecio L. & 204.78 & 7.44 & 213.4 & & & & & & & & & \\
\hline Arthraxonquartinianus (A. Rich.) Nash & 109.02 & & 1016.8 & 454.07 & & & & & & & 47.53 & \\
\hline Amaranthus hybridus $\mathrm{L}$. & 254.1 & 52.59 & 360.58 & 0.72 & 280.89 & 26.87 & 392.63 & & & & & \\
\hline Cyperusrotundus $\mathrm{L}$. & & & 20.99 & & 46.97 & 1.78 & & & & & & \\
\hline Vernonia Schreb. & & & 167.08 & 51.26 & & & 588.46 & 13.14 & 434.4 & 184.38 & & \\
\hline Cymbopogon densiflorus (Steud.) Stapf & & & & & & & & & & & 53.78 & \\
\hline Chondrillajuncea L. & & & & & & & & & & & 247.96 & 6.86 \\
\hline Crassocephalum Moench. & & & & & 100.88 & 7.38 & & & & & 75.92 & \\
\hline Conyzacordata Kuntze & & & & & & & 192.84 & 17.62 & & & & \\
\hline Kyllinga alba Nees. & 91.92 & 0.69 & & & & & & & & & & \\
\hline
\end{tabular}


Table 3. Mean concentration of $\mathrm{Zn}(\mathrm{mg} / \mathrm{kg})$ in the plant species in the sampling sites.

\begin{tabular}{|c|c|c|c|c|c|c|c|c|c|c|c|c|}
\hline \multirow[b]{2}{*}{ Species } & \multicolumn{2}{|c|}{ N1 } & \multicolumn{2}{|c|}{$\mathrm{N} 2$} & \multicolumn{2}{|c|}{ E1 } & \multicolumn{2}{|c|}{$\mathrm{S} 1$} & \multicolumn{2}{|c|}{ W1 } & \multicolumn{2}{|c|}{ W2 } \\
\hline & Mean & $\begin{array}{l}\text { SE of } \\
\text { Mean }\end{array}$ & Mean & $\begin{array}{l}\text { SE of } \\
\text { Mean }\end{array}$ & Mean & $\begin{array}{l}\text { SE of } \\
\text { Mean }\end{array}$ & Mean & $\begin{array}{l}\text { SE of } \\
\text { Mean }\end{array}$ & Mean & $\begin{array}{l}\text { SE of } \\
\text { Mean }\end{array}$ & Mean & $\begin{array}{l}\text { SE of } \\
\text { Mean }\end{array}$ \\
\hline Crinum $\mathrm{L}$. & 28.82 & 0.28 & & & & & & & & & 26.47 & \\
\hline Anthephora Schreb. & 41.19 & 5.18 & 38.15 & 9.29 & 76.76 & 1.57 & 83.81 & 3.13 & 55.47 & 1.22 & 29.08 & 1.3 \\
\hline Sp 21 & 64.68 & & & & & & & & 61.82 & 0.77 & & \\
\hline Sp 27 & 34.64 & 1.42 & 31.06 & & & & & & & & 105.7 & 20.58 \\
\hline Nephrolepis Schott & 53.63 & 4.45 & & & 46.14 & 22.15 & & & & & 55.83 & 1.49 \\
\hline Senecio L. & 108.6 & 5.63 & 87.34 & & & & & & & & & \\
\hline Arthraxonquartinianus (A. Rich.) Nash & 72.71 & & 192.4 & 61.65 & & & & & & & 38.84 & \\
\hline Amaranthus hybridus $\mathrm{L}$. & 48.24 & 4.7 & 61.26 & 1.08 & 54.98 & 4.55 & 65.22 & & & & & \\
\hline Cyperusrotundus $\mathrm{L}$. & & & 27.21 & & 38.7 & 0.64 & & & & & & \\
\hline Vernonia & & & 69.95 & 3.66 & & & 31.9 & 0.66 & 53.75 & 2.9 & & \\
\hline Cymbopogon densiflorus (Steud.) Stapf & & & & & & & & & & & 44.9 & \\
\hline Chondrillajuncea L. & & & & & & & & & 59.04 & 2.26 & & \\
\hline Crassocephalum Moench. & & & & & 57.66 & 1.97 & & & & & 52.74 & \\
\hline Conyzacordata Kuntze & & & & & & & 91.51 & 3.43 & & & & \\
\hline Kyllinga alba Nees. & 33.06 & 0.88 & & & & & & & & & & \\
\hline
\end{tabular}

Table 4. Correlation between $\mathrm{Cu}$ concentration in the soil and in the plant species.

\begin{tabular}{|c|c|c|c|}
\hline & & Soil Cu Concentration & Concentration of Copper in the plants \\
\hline \multirow{3}{*}{ Soil $\mathrm{Cu}$ concentration } & Pearson Correlation & 1 & $0.376^{* *}$ \\
\hline & Sig. (2-tailed) & & 0.000 \\
\hline & $\mathrm{N}$ & 175 & 175 \\
\hline \multirow{2}{*}{$\begin{array}{l}\text { Concentration of Copper } \\
\text { in the plants }\end{array}$} & Pearson Correlation & $0.376^{\star \star}$ & 1 \\
\hline & $\mathrm{N}$ & 175 & 175 \\
\hline
\end{tabular}

${ }^{* *}$ Correlation is significant at the 0.01 level (2-tailed).

Table 5. Correlation between concentration of $\mathrm{Zn}$ in the soil and in the plant species.

\begin{tabular}{|c|c|c|c|}
\hline & & Soil Zn concentration & Concentration of Zinc in the Plants \\
\hline \multirow{3}{*}{ Soil $\mathrm{Zn}$ concentration } & Pearson Correlation & 1 & $0.359^{\star *}$ \\
\hline & Sig. (2-tailed) & & 0.000 \\
\hline & $\mathrm{N}$ & 175 & 175 \\
\hline \multirow{3}{*}{ Concentration of Zinc in the Plants } & Pearson Correlation & $0.359^{\star *}$ & 1 \\
\hline & Sig. (2-tailed) & 0.000 & \\
\hline & $\mathrm{N}$ & 175 & 175 \\
\hline
\end{tabular}

${ }^{* *}$ Correlation is significant at the 0.01 level (2-tailed). 
the soil is high, the concentration in the plants may be correspondingly high. This was illustrated by the high concentrations recorded in plants that were growing in the study sites having high $\mathrm{Cu}$ and $\mathrm{Zn}$ concentrations. S1 had the highest $\mathrm{Cu}$ and $\mathrm{Zn}$ concentrations recorded, $12,024.49 \mathrm{mg} / \mathrm{kg}$ and $67.99 \mathrm{mg} / \mathrm{kg}$, respectively. Digitariaeriantha had its highest $\mathrm{Cu}$ concentration recorded in S1, $1282.2 \mathrm{mg} / \mathrm{kg}$, compared to values of $578.9 \mathrm{mg} / \mathrm{kg}$ in W1, $135.61 \mathrm{mg} / \mathrm{kg}$ in N1, $144.94 \mathrm{mg} / \mathrm{kg}$ in N2, $91.4 \mathrm{mg} / \mathrm{kg}$ in W2 and $64.77 \mathrm{mg} / \mathrm{kg}$ in E1. Vernonia and Conyzacordata also had their highest $\mathrm{Cu}$ concentrations recorded in S1 (588.46 $\mathrm{mg} / \mathrm{kg}$ and $192.84 \mathrm{mg} / \mathrm{kg}$, respectively) compared to other quadrants.

This, however, is not always the case, as in some soils, high $\mathrm{Cu}$ levels have been shown to be associated with insoluble copper species which have low bioavailability of copper to plants [33]. In addition, plants differ considerably in their ability to assimilate the heavy metals rendering the relationship between soil metal content and metal content in plants unpredictable [34].

\subsection{Types of Plants Growing at the Study Site}

Despite the presence of very toxic concentrations of heavy metals such as $\mathrm{Zn}$ and $\mathrm{Cu}$, it is very unlikely to find the tailings dumps or the areas surrounding them devoid of vegetation [35]. This is because there are plants that are able to tolerate the highly toxic concentrations of heavy metals. Most plants collected were annual or perennial herbs and grasses. Some are endemic to Zambia or sub-Saharan Africa, but they are not exclusively endemic to metalliferous areas. Some of the plant species collected have been noted in other parts of the country which do not have metalliferous soils [36]. Since these plants can grow naturally on both metal enriched soils and on no metalliferous soils, they are categorized as pseudometallophytes [37].

A total of 16 plant species were studied, of which, 14 were identified to genus level. Five were from the family Asteraceae, four from family Poaceae, two from Cyperaceae, and one each from Amaryllidaceae, Lomariopsidaceae and Amaranthaceae (Appendix 1). In terms of growth habit, nine were herbs, one fern and six grasses.

Of the quadrats studied, N1 was more diverse (species richness $=35 \%)$ followed by W2 and N2 (species richness $=18 \%$ in both quadrats), while W1 (species richness $=8 \%$ ) was the least diverse (Figure 2). Species with the highest densities and frequencies were Anthephora and Digitariaeriantha (density $=39.5$ and 40 , respectively; frequency $=83.33 \%$ each) $($ Table 6$)$. These two plant species also had a higher abundance (abundance $=47.4$ and 48 respectively) and the least abundant was Crassocephalum (abundance $=4$ ) and Chondrillajuncea (abundance $=3$ ) (Table 6).

Similarity indices showed that N1 and N2 were very similar with respect to species present. S1 and W1 were also quite similar. However, S1 and W2, W1 and W2, were not similar at all. All in all, TD4 and the area $50 \mathrm{~m}$ away from it are about $81 \%$ similar. The Shannon-Weiner diversity index $(\mathrm{H})$ was found to be 


\section{Species Richness}

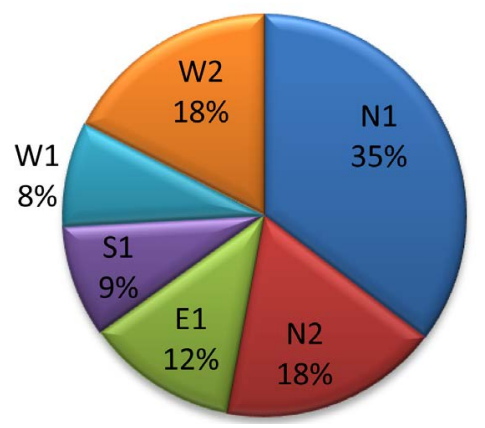

Figure 2. Species richness of the quadrants.

Table 6. Table showing the relative frequency, density and abundance for the species studied.

\begin{tabular}{|c|c|c|c|c|c|c|c|}
\hline Species & $\begin{array}{c}\text { No. of } \\
\text { Individuals }\end{array}$ & Frequency (\%) & $\begin{array}{l}\text { Relative } \\
\text { Frequency }\end{array}$ & Density & $\begin{array}{l}\text { Relative } \\
\text { Density }\end{array}$ & Abundance & $\begin{array}{l}\text { Relative } \\
\text { abundance }\end{array}$ \\
\hline Crinum $\mathrm{L}$. & 9 & 33.33 & 1.1 & 1.5 & 1.1 & 4.5 & 1.5 \\
\hline Anthephora Schreb. & 237 & 83.33 & 29.08 & 39.5 & 29.08 & 47.4 & 15.83 \\
\hline Digitariaeriantha Stued. & 240 & 83.33 & 29.45 & 40 & 29.45 & 48 & 16.03 \\
\hline Sp 21 & 16 & 50 & 1.96 & 2.67 & 1.97 & 5.33 & 1.78 \\
\hline Sp 27 & 32 & 50 & 3.93 & 5.33 & 3.92 & 10.66 & 3.56 \\
\hline Nephrolepis Schott & 29 & 50 & 0.25 & 4.83 & 3.56 & 9.67 & 3.23 \\
\hline Senecio L. & 16 & 33.33 & 1.96 & 2.67 & 1.97 & 8 & 2.67 \\
\hline $\begin{array}{l}\text { Arthraxonquartinianus (A. } \\
\text { Rich.) Nash }\end{array}$ & 29 & 50 & 0.25 & 4.83 & 3.56 & 9.67 & 3.23 \\
\hline Amaranthus L. & 34 & 50 & 4.17 & 5.67 & 4.17 & 11.33 & 3.78 \\
\hline Cyperusrotundus $\mathrm{L}$. & 11 & 33.33 & 1.35 & 1.83 & 1.35 & 5.5 & 1.84 \\
\hline Vernonia Schreb. & 28 & 50 & 3.44 & 4.67 & 3.43 & 9.33 & 3.12 \\
\hline $\begin{array}{c}\text { Cymbopogon densiflorus } \\
\text { (Steud.) Stapf }\end{array}$ & 15 & 16.67 & 1.84 & 2.5 & 1.84 & 15 & 5.01 \\
\hline Chondrillajuncea L. & 3 & 16.67 & 0.37 & 0.5 & 0.37 & 3 & 1 \\
\hline Crassocephalum Moench. & 8 & 33.33 & 0.98 & 1.33 & 0.98 & 4 & 1.34 \\
\hline Conyzacordata Kuntze & 79 & 16.67 & 9.69 & 13.17 & 9.7 & 79 & 26.39 \\
\hline Kyllinga alba Nees. & 29 & 16.67 & 0.25 & 4.83 & 3.56 & 29 & 9.69 \\
\hline
\end{tabular}

2.31 for the control site and 1.84 for TD4. This indicated that there was a richer diversity in the control site compared to TD4.

\subsection{Correlation between Shannon-Weiner Diversity Index and Soil Metal Concentration}

A negative, but significant correlation was found between the concentration of $\mathrm{Cu}$ and $\mathrm{Zn}$ in the soil, and the Shannon-Weiner diversity index (Table 7 and Table 8). This means that an increase in $\mathrm{Cu}$ and $\mathrm{Zn}$ concentration in the soil would result in a decrease in plant species diversity. 
Table 7. Correlation between plant species diversity and $\mathrm{Cu}$ concentration in the soil.

\begin{tabular}{lccc}
\hline & & $\begin{array}{c}\text { Plant Species } \\
\text { diversity }\end{array}$ & Soil_Cu_Concentration \\
\hline & Pearson Correlation & 1 & -0.716 \\
Plant Species diversity & Sig. (2-tailed) & & -0.110 \\
& $\mathrm{~N}$ & 6 & 6 \\
Soil_Cu_Concentration & Pearson Correlation & -0.716 & 1 \\
& Sig. (2-tailed) & -0.110 & 6 \\
\hline
\end{tabular}

Table 8. Correlation between plant species diversity and $\mathrm{Zn}$ concentration in the soil.

\begin{tabular}{lccc}
\hline & & $\begin{array}{c}\text { Plant Species } \\
\text { diversity }\end{array}$ & Soil_Zn_concentration \\
\hline & Pearson Correlation & 1 & -0.648 \\
Plant Species diversity & Sig. (2-tailed) & & -0.164 \\
& N & 6 & 6 \\
& Pearson Correlation & -0.648 & 1 \\
Soil_Zn_concentration & Sig. (2-tailed) & -0.164 & 6 \\
& N & 6 & \\
\hline
\end{tabular}

This highlights the effects of heavy metal pollution in soil on the biodiversity. These findings are corroborated by Vangronsveld et al. (1996) in Chibuike and Obiora [38] who reported that the diversity of higher plant species was very low in areas which were polluted with $\mathrm{Zn}$ and $\mathrm{Cu}$. Similarly, Bagatto and Shorthouse [39] noted that an increase in $\mathrm{Cu}$ concentration in the soil resulted in a decrease in floral diversity. As such, heavy metal concentration in the soil can predict the species diversity in polluted areas [40]. The effect of heavy metal toxicity, however, varies according to the specific metal involved, but overall impact on the species diversity is negative.

\subsection{Categorization of Plants Based on Their Bioaccumulation Factors}

Nearly all values of $\mathrm{Cu}$ and $\mathrm{Zn}$ concentrations recorded in the plants were higher than the recommended values. Nonetheless, plants have developed mechanisms that allow them to thrive in toxic environments. And it is these plants that have a high probability of being potential phytoremediators. Excluders only tolerate metals in the substrate by restricting the uptake of metals into the roots [15]. Accumulators on the other hand present specialized mechanisms that allow them to accumulate or even hyperaccumulate metals in their shoots [12].

Hyperaccumulation of $\mathrm{Zn}$ is exceptionally rare due to the readiness with which it can be precipitated as the insoluble sulfate in the rhizosphere, thus minimizing the probable uptake and transport to the shoots of the plants [36]. In various research conducted so far, 13 taxa have been identified as $\mathrm{Zn}$ hyperac- 
cumulators [36]. The bioaccumulation factors calculated showed that Crinum (BAF $=0.86)$ is a $\mathrm{Zn}$ excluder, Arthraxonquartinianus (BAF $=10.77$ ) is a $\mathrm{Zn}$ hyperaccumulator and the remaining 14 species (BAF ranging from $1.07-4.12$ ) are all $\mathrm{Zn}$ accumulators (Table 9 ).

A number of $\mathrm{Cu}$ hyperaccumulators have been identified all over the world which include Beciumcentralafricanum, Bulbostyliscupricola, Pimpinella acutidentata, Cheilanthesperlanata, Eragrostisracemosa, Bulbostylispseudoperennis, Aspilia ciliate and Glycine wightiivar. Longicaud, Conyzacordata, Persicariapuncata and Persicariacapitata [22] [23] [41] [42]. However, in this study, no $\mathrm{Cu}$ hyperaccumulator was identified. All the plant species were found to be $\mathrm{Cu}$ excluders (BAF ranging from 0.01 to 0.77 ) (Table 10).

It is possible that part of the measured $\mathrm{Cu}$ and $\mathrm{Zn}$ in the plant samples may have been from external deposition not removed completely during sample washing. Faucon et al. in Ghaderian and Ravandi [36] highlighted the fact that improperly washed specimen tended to have relatively high concentration values of heavy metals, hence the need to carry out further research on plant species identified tentatively as hyperaccumulators.

The high number of $\mathrm{Zn}$ and $\mathrm{Cu}$ excluders found in this study attests to findings of other researchers that the majority of metal tolerant plants colonizing mineral wastes are excluders [36] [42].

Table 9. Categorization of plant species based on their BAF Cu values.

\begin{tabular}{|c|c|c|c|}
\hline & Species & BAF (TD4) & $\begin{array}{l}\text { BAF (Immediate } \\
\text { Vicinity) }\end{array}$ \\
\hline \multirow{16}{*}{ Excluders } & Crinum $\mathrm{L}$. & & 0.01 \\
\hline & Anthephora Schreb. & 0.04 & 0.02 \\
\hline & Digitariaeriantha Steud. & 0.1 & 0.04 \\
\hline & $S p 21$ & 0.77 & - \\
\hline & $S p 27$ & 0.04 & 0.35 \\
\hline & Nephrolepis Schott. & 0.03 & 0.05 \\
\hline & Senecio L. & & 0.24 \\
\hline & Arthraxonquartinianus (A. Rich.) Nash. & - & 0.5 \\
\hline & Amaranthus hybridus $\mathrm{L}$. & & 0.07 \\
\hline & Cyperusrotundus $\mathrm{L}$. & 0.01 & 0.02 \\
\hline & Vernonia Schreb. & 0.1 & 0.15 \\
\hline & Cymbopogon densiflorus (Steud.) Stapf. & - & 0.01 \\
\hline & Chondrillajuncea L. & & 0.35 \\
\hline & Crassocephalum Moench. & - & 0.01 \\
\hline & Conyzacordata Kuntze. & 0.03 & - \\
\hline & Kyllinga alba Nees. & 0.09 & - \\
\hline
\end{tabular}


Table 10. Categorization of plants based on their BAF $\mathrm{Zn}$ values.

\begin{tabular}{|c|c|c|c|}
\hline & Species & BAF (TD4) & $\begin{array}{l}\text { BAF (immediate } \\
\text { vicinity) }\end{array}$ \\
\hline \multirow[t]{8}{*}{ Excluders } & Crinum $\mathrm{L}$. & - & 0.86 \\
\hline & Anthephora Schreb. & 1.73 & 1.26 \\
\hline & Digitariaeriantha Steud. & 1.89 & 1.07 \\
\hline & $S p 21$ & 2.3 & - \\
\hline & $S p 27$ & 1.28 & 3.92 \\
\hline & Nephrolepis Schott. & 1.68 & 1.93 \\
\hline & Senecio L. & - & 4.12 \\
\hline & Amaranthus hybridus $\mathrm{L}$. & - & 2.05 \\
\hline \multirow{7}{*}{ Accumulators } & Cyperusrotundus $\mathrm{L}$. & 1.22 & 1.31 \\
\hline & Vernonia Schreb. & 1.91 & 3.18 \\
\hline & Cymbopogon densiflorus (Steud.) Stapf. & - & 1.66 \\
\hline & Chondrillajuncea L. & - & 1.95 \\
\hline & Crassocephalum Moench. & - & 1.95 \\
\hline & Conyzacordata Kuntze. & 1.56 & - \\
\hline & Kyllinga alba Nees. & 1.26 & - \\
\hline Hyperaccumulator & Arthraxonquartinianus (A. Rich.) Nash & - & 10.77 \\
\hline
\end{tabular}

\section{Conclusions}

With respect to Zinc, Crinum was found to be an excluder, Arthraxonquartinianus a hyperaccumulator, while the remaining plant species were accumulators. All the 16 plant species were found to be $\mathrm{Cu}$ excluders. The plant species identified in this study, thus, have potential for phytoremediation as excluders, accumulators and hyperaccumulators. They represent potential for remediation of soils heavily polluted by heavy metals.

Further research needs to be done to identify indigenous plants with potential for phytoremediation of other heavy metals such as Cobalt, Nickel, Lead and Cadmium.

\section{Acknowledgements}

Special thanks to the Ministry of Higher Education for the financial assistance and Konkola Copper Mines Plc. for the technical support.

\section{Conflicts of Interest}

The authors declare no conflicts of interest regarding the publication of this paper.

\section{References}

[1] Ngoma, J. (2011) What Would It Take for Zambia's Copper Mining Industry to 
Achieve Its Potential?

http://siteresources.worldbank.org/INTZAMBIA/Resources/Additional Jobs and Prosperity Report Summaries-Copper Mining.pdf

[2] Sheoran, V., Sheoran, A.S. and Poonia, P. (2010) Soil Reclamation of Abandoned Mine Land by Revegetation: A Review. International Journal of Soil, Sediment and Water, 3, Article No. 13.

[3] Miao, Z.-W., Bai, Z.-K. and Gao, L. (2000) Ecological Rebuilding and Land Reclamation in Surface Mines in Shanxi Province, China. Journal of Environmental Sciences, 12, 486-497.

[4] Kumar, N., Kumar, A. and Singh, M. (2014) Floristic Diversity Assessment in Ecologically Restored Limestone (Building Stone) Mine Near Checha Village, Kata District, Rajasthan. Ecologia, 4, 16-25. https://doi.org/10.3923/ecologia.2014.16.25

[5] Shen, Z.-G., Li, X.-D., Wang, C.-C., Chen, H.-M. and Chua, H. (2002) Lead Phytoextraction from Contaminated Soil with High Biomass Plant Species. Journal of Environmental Quality, 31, 1893-1900. https://doi.org/10.2134/jeq2002.1893

[6] Malayeri, B.E., Chehregani, A., Yousefi, N. and Lorestani, B. (2008) Identification of the Hyperaccumulator Plants in Copper and Iron Mine in Iran. Pakistan Journal of Biological Sciences, 11, 490-492. https://doi.org/10.3923/pjbs.2008.490.492

[7] Ghosh, M. and Singh, S.P. (2005) A Review on Phytoremediation of Heavy Metals and Utilization of by-Products. Applied Ecology and Environmental Research, 73, 1-18. https://doi.org/10.15666/aeer/0301 001018

[8] National Resources Conservation Service (2006) Land Reclamation, Currently Mined Land. http://www.nrcs.usda.gov/Internet/FSE DOCUMENTS/stelprdb1253605.pdf

[9] Mehes-Smith, M., Nkongolo, K. and Cholewa, E. (2013) Coping Mechanisms of Plants to Metal Contaminated Soil. https://doi.org/10.5772/55124

[10] Aboulroos, S.A., Helal, M.I.D. and Kamel, M.M. (2006) Remediation of Pb and Cd Polluted Soils Using in Situ Immobilization and Phytoextraction Techniques. Soil Sediment Contamination, 15, 199-215. https://doi.org/10.1080/15320380500506362

[11] Lorestani, B., Cheraghi, M. and Yousefi, N. (2011) Phytoremediation Potential of Native Plants Growing on a Heavy Metals Contaminated Soil of Copper Mine in Iran. International Scholarly and Scientific Research and Innovation, 5, 1-6.

[12] Jadia, C.D. and Fulekar, M.H. (2009) Phytoremediation of Heavy Metals: Recent Techniques. African Journal of Biotechnology, 8, 921-928.

[13] Susarla, S., Medina, V.F. and McCutcheon, S.C. (2002) Phytoremediation: Ze-Wei, M., Zhong-Ke, B. and Lin, G. (2000) Ecological Rebuilding and Land Reclamation in Surface Mines in Shanxi Province, China. Journal of Environmental Sciences, 12, 486-497.

[14] Ssenku, J.E., Ntale, M., Backeus, I., Lehtila, K. and Oryem-Origa, H. (2014) Dynamics of Plant Species during Phytostabilisation of Copper Mine Tailings and Pyrite Soils, Western Uganda. Journal of Environmental Engineering and Ecological Science, 3, Article No. 4. https://doi.org/10.7243/2050-1323-3-4

[15] Baker, A.J.M. (1981) Accumulators and Excluders-Strategies in the Response of Plants to Heavy Metals. Journal of Plant Nutrition, 3, 643-654. https://doi.org/10.1080/01904168109362867

[16] Baker, A.J.M. and Brooks, R.R. (1989) Terrestrial Higher Plants Which Hyperaccumulate Metallic Elements: A Review of Their Distribution, Ecology and Phytochemistry. Biorecovery, 1, 81-126. 
[17] Mcgath, S.P. and Zhao, F.J. (2003) Phytoextraction of Metals and Metalloids from Contaminated Soils. Current Opinions in Biotechnology, 14, 277-282. https://doi.org/10.1016/S0958-1669(03)00060-0

[18] Nazir, A., Malik, R.N., Ajaib, M., Khan, N. and Siddiqui, M.F. (2011) Hyperaccumulators of Heavy Metals of Industrial Areas of Islamabad and Rawalpindi. Pakistani Journal of Botany, 43, 1925-1933.

[19] Sharma, P. and Pandey, S. (2014) Status of Phytoremediation in World Scenario. International Journal of Environmental Bioremediation and Biodegradation, 2, 178-191.

[20] Mwegoha, W.J.S. (2008) The Use of Phytoremediation Technology for Abatement of Soil and Groundwater Pollution in Tanzania: Opportunities and Challenges. Journal of Sustainable Development in Africa, 10, 140-156.

http://www.jsd-africa.com/Jsda/V10N1 Spring2008/PDF/UseofPhytoremediation.p df

[21] Lorestani, B., Cheraghi, M. and Yousefi, N. (2011) Accumulation of Pb, Fe, Mn, Cu and $\mathrm{Zn}$ in Plants and Choice of Hyperaccumulator Plant in the Industrial Town of Vian, Iran. Archives of Biological Science, Belgrade, 63, 739-745. https://doi.org/10.2298/ABS1103739L

[22] Sarma, H. (2011) Metal Hyperaccumulation in Plants: A Review Focusing on Phytoremediation Technology. Journal of Environmental Science and Technology, 4, 118-138. https://doi.org/10.3923/jest.2011.118.138

[23] Leteinturier, B., Baker, A.J.M., Bock, L., Matera, J., Malaisse, F. and Malaise, F. (2001) Copper and Vegetation at the Kansanshi Hill (Zambia) Copper Mine. Belgian Journal of Botany, 134, 41-50.

[24] Van der Ent, A., Erskine, P., Mulligan, D., Vinya, R., Maseka, K.K. and Siame, J. (2015) The Potential of Zambian Copper-Cobalt Hyperaccumulator Plants for Phytoremediation of Polluted (Mining/Smelter) Soils. International Mining for Development Centre Action Research Report.

[25] Central Statistics Office (2011) 2010 Census of Population of Housing: Preliminary Population Figures. Zambia, Lusaka, 7-8.

[26] Konkola Copper Mines (2014) TD2 New Slag Dump Project: Environmental and Social Impact Statement. URS Scott Wilson, Kitwe.

[27] Curtis, J.T. and McIntosh, R.P. (1950) The Interrelations of Certain Analytic and Synthetic Phytosociological Characters. Ecology, 31, 434-455. https://doi.org/10.2307/1931497

[28] Magurran, A.E. (1988) Ecological Diversity and Its Measurements. Chapman and Hall, London, United Kingdom. https://doi.org/10.1007/978-94-015-7358-0

[29] Usman, A.R.A., Lee, S.S., Awad, M.Y., Lim, K.J., Yang, J.E. and Ok, Y.S. (2012) Soil Pollution Assessment and Identification of Hyperaccumulating Plants in Chromate Copper Arsenate (CCA) Contaminated Sites, Korea. Chemosphere, 87, 872-878. https://doi.org/10.1016/j.chemosphere.2012.01.028

[30] Ruqia, N., Muslin, K., Muhammad, M., Hameed, U.R., Naveed, U.R., Surrya, S., Nosheen, A., Muhammad, S., Mohib, U., Muhammad, R. and Zeenat, S. (2015) Accumulation of Heavy Metals ( $\mathrm{Ni}, \mathrm{Cd}, \mathrm{Cu}, \mathrm{Cr}, \mathrm{Pb}, \mathrm{Zn}, \mathrm{Fe}$ ) in the Soil, Water and Plants, and Analysis of Physico-Chemical Parameters of Soil and Water Collected from Tanda Dam Kohat. Journal of Pharmaceutical Sciences and Research, 7, 89-97.

[31] Interdepartmental Committee on the Redevelopment of Contaminated Land (ICRCL) (1987) Guidance on Assessment and Redevelopment of Contaminated 
Land. 2nd Edition, ICRCL Central Directorate on Environmental Protection, Department of the Environment Circular 59/83, London.

[32] Rodricks, J.A. (1992) Calculated Risks: The Toxicity and Human Health Risks of Chemicals in Our Environment. Cambridge University Press, New York.

[33] Badilla-Ohlbaum, R., Ginocchi, R., Rodriquez, P.H., Cespedes, A., Gonzales, S., Allen, H.E. and Laqos, G.E. (2001) Relationship between Soil Copper Content and Copper Content of Selected Crop Plants in Central Chile. Environmental Toxicology and Chemistry, 20, 2749-2757. https://doi.org/10.1002/etc.5620201214

[34] Robert, D.D. (1979) Uptake of Copper, Nickel, and Zinc by Crops Growing in Contaminated Soils. Journal of the Science of Food and Agriculture, 30, 937-947. https://doi.org/10.1002/jsfa.2740301002

[35] Aggangan, N.S., Pampolina, N.M., Cadiz, N.M. and Raymundo, A.K. (2015) Assessment of Plant Diversity and Associated Mycorrhizal Fungi in the Mined-out Sites of Atlas Mines in Toledo City, Cebu for Bioremediation. Journal of Environmental Science and Management, 18, 71-86.

[36] Phiri, P.S.M. (2005) A Checklist of Zambian Vascular Plants. Southern African Botanical Diversity Network Report No. 32. SABONET, Pretoria.

[37] Ghaderian, M.S. and Ravandi, G.A.A. (2012) Accumulation of Copper and Other Heavy Metals by Plants Growing on Sarcheshmeh Copper Mining Area, Iran. Journal of Geochemical Exploration, 123, 25-32. https://doi.org/10.1016/j.gexplo.2012.06.022

[38] Chibuike, G.U. and Obiora, S.C. (2014) Heavy Metal Polluted Soils: Effect on Plants and Bioremediation Methods. https://doi.org/10.1155/2014/752708

[39] Bagatto, G. and Shorthouse, J.D. (1999) Biotic and Abiotic Characteristics of Ecosystems on Metalliferous Mine Tailings Near Sudbury, Ontario. Canadian Journal of Botany, 77, 410-425. https://doi.org/10.1139/b98-233

[40] Koptsik, S., Koptsik, G., Livantsova, S., Eruslankina, I., Zhmelkova, T. and Vologdina, Z. (2003) Heavy Metals in Soils Near the Nickel Smelter: Chemistry, Spatial Variation and Impacts on Plant Diversity. Journal of Environmental Monitoring, 5, 441-450. https://doi.org/10.1039/b210397b

[41] Malaisse, F., Brooks, R.R. and Baker, A.J.M. (1994) Diversity of Vegetation Communities in Relation to Soil Heavy Metal Content at the Shinkolobwe Copper/Cobalt/Uranium Mineralization, Upper Shaba, Zaire. Belgian Journal of Botany, 127, 3-16.

[42] Malaisse, F., Baker, A.J.M. and Ruelle, S. (1999) Diversity of Plant Communities and Leaf Heavy Metal Content at Luiswishi Copper/Cobalt Mineralization, Upper Katanga, Democratic Republic of Congo. Biotechnology, Agronomy, Society and Environment, 3, 104-114. 


\section{Appendix 1}

Table A1. List of plant species studied.

\begin{tabular}{lccc}
\hline \multicolumn{1}{c}{ Plant species } & Family & Habit & Life Cycle \\
\hline Crinum L. & Amaryllidaceae & Herb & Perennial \\
Anthephora Schreb. & Poaceae & Grass & Perennial \\
Digitariaeriantha Stued. & Poaceae & Grass & Perennial \\
Sp 21 & n.a. & Herb & n.a. \\
Sp 27 & n.a. & Herb & n.a. \\
Nephrolepis Schott & Lomariopsidaceae & Fern & Perennial \\
Senecio L. & Asteraceae & Herb & Perennial \\
Arthraxonquartinianus (A. Rich.) Nash & Poaceae & Grass & Perennial \\
Amaranthus hybridus L. & Amaranthaceae & Herb & Annual \\
Cyperusrotundus L. & Cyperaceae & Grass & Perennial \\
Vernonia Schreb. & Asteraceae & Herb & Perennial \\
Cymbopogon densiflorus (Steud.) Stapf & Poaceae & Grass & Perennial \\
Chondrillajuncea L. & Asteraceae & Herb & Perennial \\
Crassocephalum Moench. & Asteraceae & Herb & Annual \\
Conyzacordata Kuntze & Asteraceae & Herb & Perennial \\
Kyllinga alba & Cyperaceae & Grass & Perennial \\
\hline
\end{tabular}

